\title{
PELATIHAN BAHASA INGGRIS JURUSAN KEPERAWATAN POLTEKKES DENPASAR
}

\author{
I Made Juliarta ${ }^{1^{*}}$ \\ ${ }^{1}$ Program Studi Bahasa Inggris, Universitas Bali Dwipa \\ ${ }^{*}$ Coresponding-Author : madejuliarta330@gmail.com
}

\begin{abstract}
ABSTRAK. Kegiatan pengabdian kepada masyarakat ini bertujuan untuk meningkatkan kemampuan mahasiswa dalam menguasai Bahasa Inggris Keperawatan. Pelatihan Bahasa Inggris keperawatan ini diberikan melalui video conference zoom yang bisa dilakukan oleh mahasiswa di dalam melakukan kegiatan pembelajaran. Di dalam suasana pandemik Covid-19 ini, pelaksanaan kegiatan dilaksanakan secara daring, dan menjadi tantangan baru bagi para pendidik dan siswa di dalam mengikuti kegiatan pembelajaran. PKM ini diprakarsai oleh pendidik sendiri dengan mahasiswa jurusan Keperawatan Poltekkes Denpasar di dalam memberikan pelatihan Bahasa Inggris ini. Metode persuasif merupakan metode yang digunakan dalam proses pembelajaran Bahasa Inggris Keperawatan agar mahasiswa lebih tertarik mempelajari bahasa Inggris yang berhubungan dengan dunia keperawatan. Pelatihan yang diberikan kepada peserta mahasiswa keperawatan antara lain berupa pelatihan bahasa Inggris dalam bidang keperawatan level dasar. Kontek situasi merupakan pendekatan yang digunakan di dalam proses pembelajaran ini, yang dikemukakan oleh Halliday yaitu tentang, field, tenor, dan mood. Para mahasiswa di dalam melaksanakan proses pembelajaran bahasa Inggris lewat media online, zoom tampak sangat antusias ketika menyimak pembekalan materi yang diberikan oleh pengajar sendiri. Kegiatan ini bisa membantu mahasiswa keperawatan poltekkes Denpasar di dalam memberikan pelatihan bahasa Inggris. Lokasi kampus yang tidak jauh dari Universitas Bali Dwipa memudahkan pengajar dalam memberikan koordinasi dengan mahasiswa untuk memberikan pelatihan Bahasa Inggris.
\end{abstract}

Kata Kunci: Belajar Bahasa Inggris, Mengatasi, Bahasa Inggris Keperawatan

\begin{abstract}
This community service activity aims to improve the ability of nursing students to master Nursing English. Nursing English training is provided by doing video conference zoom which can be carried out by students in doing learning activities. In the situation of the Covid-19 pandemic, the implementation of activities is carried out online, and it is a new challenge for teachers and students in participating in learning activities. A pleasant learning situation is given to students who take part in this English training activity, so as not to quickly feel bored in participating in learning. This program was initiated by the teachers themselves with nursing students from the Health Polytechnic of Denpasar in providing this English training. The persuasive method is a method used in the nursing English learning process; therefore the students are more interested in learning English related to the world of nursing. The training given to nursing student participants includes English language training in basic level nursing. Situation context is the approach used in this learning process, proposed by Halliday, those are, field, tenor, and mood. In carrying out the process of learning English through online media, zoom seemed very enthusiastic when listening to the material provided by the teacher himself. This activity can help nursing students at the Health Polytechnic of Denpasar in giving English language training. The location of the campus which is not far from Bali Dwipa University makes it easy for teachers to teach students.
\end{abstract}

Keywords: Learning English, Overcoming, Nursing English 


\section{PENDAHULUAN}

Penguasaan Bahasa International sangat penting untuk bisa bersaing di tingkat internasional. Dalam persaingan tingkat internasional, penguasaan bahasa Asing menjadi sangat penting dalam memberikan layanan kesehatan khususnya dalam bidang keperawatan. Bahasa Inggris merupakan bahasa Internasional yang sangat penting digunakan baik di dunia kerja maupun dunia pendidikan di kampus. Bali merupakan daerah dengan seribu Pura selain itu Bali juga terkenal akan seni budaya yang membuat para wisatawan mancanegara tertarik untuk mengunjungi Pulau Dewata Bali.

Adat-istiadat yang santun dan keramah-tamahan masyarakat menyebabkan Pulau Bali menjadi destinasi wisata sebagai daerah tujuan wisata Internasional. Kemajuan Pariwisata Bali dilihat dari kunjungan wisatawan mancanegara dan tentu saja mereka sebagian besar menggunakan bahasa Inggris sebagai komunikasi Internasionalnya. Oleh karena itu, masyarakat Bali diharapkan mampu berbahasa Inggris agar bisa memberikan pelayanan dalam jasa pariwisata khususnya.

Bahasa Inggris merupakan pembelajaran Bahasa yang dipergunakan di kampus, yang mana kemampuan yang harus dikuasai oleh siswa seperti penguasaan kosa-kata, pelafalan, penulisan, dan beberapa perbendaharaan kata sesuai dengan Bahasa Inggris sendiri. Pemberian kegiatan pembelajaran Bahasa Inggris di sekolah maupun kampus, belum bisa menjamin pencapaian siswa dalam berbahasa Inggris karena beberapa faktor, diantaranya adalah guru yang banyak memberikan bekal teori dibandingkan keterampilan latihan percakapan baik lisan maupun tulisan. Oleh karena itu, penguasaan Bahasa Inggris lebih banyak dilakukan dengan mengikuti pembelajaran diluar sekolah, mengikuti kursus di Lembaga Pelatihan yang sudah diterapkan oleh banyak kalangan masyarakat di Bali.

Di masa Pandemi 2019 ini, merupakan masa-masa sulit bagi mahasiswa karena proses belajar-mengajar dilakukan secara daring (online). Institusi Pendidikan mencari solusi yang tepat di dalam memberikan pembelajaran secara daring (online). Oleh karena itu, jurusan Bahasa Inggris Universitas Bali Dwipa memberikan solusi dengan memberikan pembelajaran secara daring (online), tentang cara mempermudah mahasiswa untuk belajar dan untuk meningkatkan minat mahasiswa di dalam pembelajaran daring melalui kegiatan pengabdian kepada masyarakat (PKM). Kegiatan ini memiliki tujuan untuk menghasilkan mahasiswa-mahasiswa yang terampil dalam berbahasa Inggris, sehingga bisa bersaing di tingkat nasional maupun Internasional. Sasaran utama yang menjadi peserta PKM adalah mahasiswa Jurusan Keperawatan POLTEKKES Denpasar yang berlokasi tidak jauh dari kampus Universitas Bali Dwipa.

Pelatihan Bahasa Inggris ini dapat menjadi solusi bagi mahasiswa Jurusan Keperawatan POLTEKKES Denpasar, di dalam meningkatkan kemampuan Bahasa Inggris di masa pandemik COVID-19 ini. Peningkatan kemampuan bahasa Inggris ini bisa berupa latihan percakapan, menulis, menerjemahkan, yang di lakukan oleh mahasiswa secara online. Terdapat tiga elemen bahasa yang memiliki peranan penting di dalam meningkatkan kemampuan bahasa Inggris, yaitu: pelafalan, kosa-kata, dan struktur kata.

\section{SOLUSI YANG DITAWARKAN}

Metode persuasif merupakan metode yang digunakan dalam proses pembelajaran Bahasa Inggris Keperawatan agar mahasiswa lebih tertarik mempelajari bahasa Inggris yang berhubungan dengan dunia keperawatan. Pelatihan yang diberikan kepada peserta mahasiswa keperawatan antara lain berupa pelatihan bahasa Inggris dalam bidang keperawatan level dasar. Penyebaran angket, rekaman dan observasi merupakan teknik pengumpulan data yang digunakan. Angket kemudian disebarkan kepada mahasiswa jurusan Keperawatan Poltekkes Denpasar, untuk mengetahui respon tentang pengalaman belajar bahasa Inggris selama pelatihan Bahasa Inggris 
berlangsung. Peneliti menggunakan rekaman di dalam mengumpulkan data. Setelah selesai mengumpulkan data, kemudian dilanjutkan dengan menggunakan analisis deskriptif.

\section{HASIL DAN PEMBAHASAN}

Pelatihan Bahasa Inggris ini diberikan kepada mahasiswa Jurusan Keperawatan Poltekkes Denpasar. Adapun 3 tahapan kegiatan yang diberikan di dalam memberikan pelatihan Bahasa Inggris ini yaitu kegiatan percakapan Bahasa Inggris, membaca, dan melakukan kegiatan role play. Ada beberapa persiapan yang dilakukan sebelum melakukan kegiatan pengabdian kepada masyarakat, antara lain adalah melakukan observasi lapangan sebelum melakukan pelaksanaan pengabdian kepada masyarakat, menyusun proposal kegiatan, dan membuat materi kegiatan. Ketika melakukan observasi lapangan sebelum melaksanakan kegiatan Pengabmas, dilakukan kunjungan ke lokasi kegiatan yaitu di kampus Jurusan Keperawatan, Jalan Pulau Moyo, Pedungan. Kunjungan ini dilakukan untuk melakukan koordinasi kepada sipen atau perwakilan kelas keperawatan sebelum melaksanakan kegiatan pelatihan bahasa Inggris dalam bentuk webinar Zoom. Kemudian dilanjutkan dengan melakukan koordinasi mengenai jadwal kegiatan melalui pesan singkat yang diberikan oleh pengajar kepada sipen yang merupakan ketua kelompok dalam kelas keperawatan. Informasi mengenai model atau metode kegiatan pelatihan juga di dapat di dalam kegiatan observasi, sehingga mahasiswa mendapatkan informasi yang jelas sebelum mengikuti pelatihan bahasa Inggris Keperawatan. Observasi ini bertujuan untuk mengecek kesiapan mahasiswa sebelum melaksanakan kegiatan pembelajaran atau pelatihan Bahasa Inggris yang dilakukan secara daring atau online. Observasi bertujuan untuk mengetahui jumlah peserta yang akan mengikuti pelatihan Bahasa Inggris Jurusan Keperawatan Poltekkes Denpasar. Jumlah mahasiswa Keperawatan yang akan mengikuti kegiatan pelatihan Bahasa Inggris ini dilakukan dengan berkoordinasi dengan ketua kelompok Bahasa Inggris.

Menyusun proposal kegiatan pelatihan Bahasa Inggris merupakan langkah pertama yang dilakukan di dalam pelatihan Bahasa Inggris yang dilakukan secara daring (online). Di dalam melakukan kegiatan pelatihan Bahasa Inggris, terdapat empat aspek keterampilan yang diberikan di dalam pelatihan Bahasa Inggris, yaitu: mendengarkan, berbicara, membaca dan menulis. Kegiatan ini bertujuan untuk meningkatkan motivasi mahasiswa di dalam belajar Bahasa Inggris. Setelah selesai mengadakan observasi kepada mahasiswa jurusan keperawatan, kemudain dilanjutkan dengan pembelajaran daring atau online. Mahasiswa tampak sangat antusias di dalam mengikuti kegiatan belajar online yang diadakan oleh dosen jurusan prodi Bahasa Inggris Universitas Bali Dwipa. Kreativitas pengajar di dalam menentukan model dan teknik pembelajaran keterampilan berbicara maupun menulis kepada siswa sangat menentukan faktor yang menyebabkan mahasiswa antusias dalam mengikuti kegiatan pelatihan bahasa Inggris yang diselenggarakan secara daring ini. Kegiatan ini bertujuan juga untuk menarik minat mahasiswa di dalam mempelajari bahasa Inggris keperawatan. Pemahaman tentang kosa-kata yang berhubungan dengan IImu Keperawatan sangat penting guna menunjang kemampuan Bahasa Inggris keperawatan. Materi belajar yang digunakan mahasiswa Jurusan keperawtaan yaitu materi bahan ajar yang sesuai dengan kemampuan mahasiswa. Oleh karena itu, mahasiswa bisa mengikuti acara pelatihan bahasa Inggris ini dengan baik.

Proses pelatihan Bahasa Inggris ini diawali dengan greeting dalam bahasa Inggris, kemudian dilanjutkan dengan mempelajari kosa-kata yang berhubungan dengan ilmu keperawatan. Mahasiswa kemudian melakukan percakapan bahasa Inggris keperawatan. Kemudian dilanjutkan dengan mengajari mahasiswa tentang bagaimana mengucapkan kosa kata yang diberikan. Misalnya kosa kata tentang ilmu kesehatan yang berhubungan dengan bidang kerja mahasiswa yang akan dijalani setelah mereka tamat kuliah. Sehari sebelum melaksanakan kegiatan pelatihan Bahasa Inggris, mahasiswa diberikan materi pembelajaran melalui what's up group yang sudah 
dibentuk sebelumnya. Termasuk juga penjelasan yang diberikan kepada mahasiswa dalam bentuk video yang menjelaskan tentang materi pembelajaran yang akan diberikan kepada mahasiswa keperawatan.



Gambar 1. Kegiatan pelatihan Bahasa Inggris melalui zoom

\section{KESIMPULAN}

Dari hasil penelitian, dapat disimpulkan bahwa program pengabdian masyarakat dengan sasaran mahasiswa Jurusan Keperawatan sudah berjalan dengan baik dan hasilnya mampu meningkatkan pengetahuan dan kemampuan mitra yang merupakan para pelajar dalam berbahasa Inggris dan minat mahasiswa untuk belajar Bahasa Inggris meningkat. Guna mendapatkan hasil yang maksimal yang didapatkan setelah melakukan pelatihan Bahasa Inggris, mahasiswa diharapkan mempraktekkan dalam latihan percakapan Bahasa Inggris. Sehingga hasil yang didapat maksimal. Selain itu juga mahasiswa diharapkan mampu mengingat beberapa kosa-kata yang berhubungan dengan Bahasa Inggris keperawatan sehingga bisa digunakan di dalam dunia kerja ketika berhadapan langsung dengan tamu asing dalam bidang pelayanan kesehatan. Kegiatan ini sangat penting guna menunjang atau untuk meningkatkan kemampuan mahasiswa dalam penguasaan Bahasa Inggris keperawatan.

\section{REFERENSI}

Djojosuroto. 2007. Filsafat Bahasa. Yogyakarta: Pustaka Book Publisher.

Dijk, Teun A. Van. 2000. Ideology A Multidisciplinary Approach. New Dehli: Sage Publications India Ltd. Eggins, Suzanne, 2004. An Introduction to Functional Linguistics. New York: Continuum.

Halliday, M.A.K. 1978. Language as Social Semiotics.London: Edward Arnold.

Halliday, M.A.K. dan Ruqiaya Hasan. 1999. Language, Context, and Text: Aspect of Language in SocialSemiotic Perspective. London: Deikin University.

Halliday, M.A.K. 2003. The language of Early Childhood.Webster (Edditor). London: Continuum.

Halliday, M.A.K dkk 2004. Lexicology and Corpus Linguistics An Introduction. London: Continuum.

Halliday, M.A.K. 2014.Halliday's Introduction to Functional Grammar.London: Routledge.

Martin, J R. 1992. English Text System and Structure.Amsterdam: University of Sydney.

Schleppegrell, Mary J. 2008. The Language of Schooling A Functional Linguistics Perspective. London: Lawerence Erlbaum Associates, Publisher. 
Suardana, I Ketut. 2020. Teks Pan Balang Tamak Kajian Linguistik Fungsional Sistemik. Disertasi. Denpasar: Universitas Udayana. 